\title{
Investigating Chinese Outward Foreign Direct Investments: How Can Firm-level Data Help?
}

\author{
A. Amighini, C. Cozza, R. Rabellotti, M. Sanfilippo *
}

\begin{abstract}
The empirical literature on China's outward foreign direct investment mainly relies on aggregate data from official statistics, whose international reliability is currently a matter of concern, not taking account some relevant features such as the industry breakdowns, ownership structures and modes of entry. A novel firm-level database - EMENDATA compiled by matching data from several available sources, on various types of cross-border deals, and including information on group structure, enables new empirical analyses and provides new insights into the rapidly increasing presence of Chinese companies abroad. In the present paper, by exploring the potential of this database, we offer an informative and comprehensive assessment of the geographical and specialization patterns of Chinese outward FDI into Europe and suggest new avenues for further research on this highly policy relevant issue.
\end{abstract}

Keywords: China, FDI, firm-level data, MNEs

JEL: F21; F23

\section{Introduction}

* Alessia Amighini, Assistant Professor, University of Eastern Piedmont, Novara, Italy. Email: alessia.amighini@eco.unipmn.it; Claudio Cozza, Research Fellow, University of Trieste, Italy. E-mail: claudio.cozza@deams.units.it; Roberta Rabellotti, Professor, University of Pavia, Italy. E-mail: roberta.rabellotti@unipv.it; Marco Sanfilippo, Research Fellow, European University Institute, Italy. E-mail: marco.sanfilippo@eui.eu. The authors would like to thank the anonymous referees for their useful suggestions. This paper is an output of the project "The challenge of globalization: Technology driven foreign direct investment (TFDI) and its implications for the negotiation of International (bi and multilateral) Investment Agreements” funded by the Riksbank Foundation. 
The literature on the outward expansion of Chinese firms has grown rapidly in the last decade, with mixed and often contradictory results. Most of the existing studies is based on aggregate official FDI data from the Chinese Ministry of Commerce (MOFCOM) (among others see Buckely et al., 2007; Kolstad and Wiig, 2012) or on case studies on individual firms (Zhang and Filippov, 2009; Zhang et al., 2011). Despite recent improvements, a number of concerns still remain about the reliability of FDI data from MOFCOM and their comparability with international data sources. Moreover, official FDI data do not allow a disaggregated and detailed investigation of the internationalization strategies of Chinese multinational companies in terms of their preferred mode of entry, their main sectors and target countries. On the contrary, the strategy of internationalization is the focus of a number of case studies, many of them investigating the same well-known companies, providing very useful anecdotal evidence but with an obvious limitation in terms of their generalization (e.g. Fan et al., 2012).

To address these limitations, there are some recent empirical studies focusing either on greenfield FDI (Amighini and Franco, 2013; Amighini et al., 2013a, b; De Beule and van de Bulcke, 2012) or on mergers and acquisitions (M\&As) (Bhabra and Huang, 2013). In the present paper, we address the drawback of focusing on one mode of entry at the time and present a novel database - the Emerging Multinationals' Events and Networks DATAbase (EMENDATA), which includes greenfield investments, M\&As and other minority investments. The data are based on company information gathered from numerous different sources such as the Financial Times Group's fDImarkets, Bureau van Dijk's (BvD) Zephyr and Thomson Reuter's SDC Platinum. In EMENDATA each cross-border deal is associated with information available in BvD's Orbis, on the investing company and the group to which the firm belongs based on its Global Ultimate Owner (GUO). This allows us to examine the foreign expansion strategies of Chinese multinationals and their groups over time via multi-level analyses: a) at deal level to investigate the distribution across sectors, business activity, and countries distinguished by deal type; b) at company level, and more especially group level, to map foreign expansion and corporate strategies; c) at country and regional levels to examine the location choices broken down by sector and deal type. Overall, the database combines extensive macro data with in-depth company level data, typical of micro datasets.

In this paper our contribution to the literature on Chinese OFDI is twofold. On the one hand, we argue that highly debated findings on the Chinese MNEs internationalization strategies are largely influenced by the sources of data used and that with more detailed information becoming available, the interpretation of these specific features becomes less problematic. On the other hand, we introduce a new database with the objective of promoting a research agenda aimed at strengthening 
the robustness of the early findings of the literature and proposing new directions to improve the knowledge base on such a rapidly increasing phenomenon.

The rest of the paper is organized as follows. Section II presents some shortcomings of the FDI official statistics and reviews the empirical literature on the outward expansion of Chinese firms, focusing on the different data sources and the implications of their use for the empirical findings. Section III describes EMENDATA and provides an overview of its content. Section IV presents some examples of empirical analyses at the level of the company group allowed by EMENDATA. Section V concludes.

\section{Chinese Outward FDI: Data Sources and Empirical Findings}

\section{Official statistics on Chinese outward FDI: a methodological note}

In China, there are two main agencies - the State Administration of Foreign Exchange (SAFE) and MOFCOM - that collect FDI data according to different criteria. SAFE collects annual Balance of Payments (BoP) data providing an aggregate picture of China's international investment position, without a sectoral or geographic disaggregation. ${ }^{1}$ FDI flows recorded by BoP statistics comprise: a) equity capital transactions, i.e. purchases and sales by parent companies of the shares of subsidiaries registered in foreign countries; b) reinvested earnings, which are foreign affiliates' earnings that are neither distributed as dividends by affiliates nor remitted to the parent, but reinvested; c) intracompany debt transactions, which are short and long-term borrowing and lending funds between the parent and its affiliates. In BoP, FDIs are cross-border flows of financial funds measured as the difference between the transfers from parent to foreign subsidiary and those from foreign affiliate to parent firm. Thus, FDI data based on official statistics can be positive or negative figures, therefore with a major limitation because a negative figure could be wrongly understood as a reduction in the multinational activity (Beugelsdijk et al., 2010).

FDI data provided by MOFCOM are based on officially approved investments. Despite recent data improvements and the formal commitment by MOFCOM to comply with international standards, there are still some concerns about the reliability of Chinese official FDI data. ${ }^{2}$ Within the research community, there is broad consensus that there are problems of underestimation for a number of reasons explained in what follows. First, reinvested earnings and intra-company loans are not officially recorded by this source (OECD, 2008; Buckley et al., 2008). Second, at least for the

\footnotetext{
${ }^{1}$ A notable exception are the 1991-2001 data - a period when SAFE published a project level database - which include information on the foreign exchange amount approved for each investment, as well as information on geographic destination and sector (see Buckley et al., 2007 for a short description of these data). Unfortunately, this information has not been available since 2001 (Buckley et al., 2008).

${ }^{2}$ A statistical system consistent with international standards was established in 2002, and from 2003 MOFCOM (in collaboration with SAFE) began to publish official statistics on Chinese outward FDI in the annual Statistical Bulletin of China's Outward Foreign Direct Investment.
} 
period 2002-2005, they do not include FDI from financial institutions, whose approval procedure was not under the control of MOFCOM. ${ }^{3}$ Third, given that MOFCOM data are based on information recorded during the approval process rather than through surveys (mandatory by international standards), under-reporting is common practice, especially among private firms that are treated differently depending on the specific regional regulations (Davies, 2013) and which can often avoid the formal approval (OECD, 2008; Rosen and Hanemann, 2009). ${ }^{4}$ Fourth, MOFCOM data are also strongly affected by the practice of round-tripping, i.e. channeling of large investment outflows through tax havens via the establishment of special purpose entities, and reinvesting in China or in third countries (Sutherland and Ning, 2011). This is the result of a common practice among firms to register only the first destination of their investments, which results in overestimation of some transit locations with respect to the final destinations. According to the official data, up to 2011, approximately 74 percent of total Chinese outward FDI (OFDI) stock went to Hong Kong, the Cayman Islands, and the Virgin Islands, with the final location generally undisclosed (MOFCOM, 2012). Lastly, Chinese statistics do not follow the International Standard Industry Classification (ISIC) system, but are based on a domestic classification, which prevents detailed international comparisons (OECD, 2008).

There are some recent attempts to estimate differences between official Chinese statistics with disaggregated data from alternative sources. First, differences in the recorded amount of flows are significant when comparing Chinese OFDI based on MOFCOM data, with inward FDI recorded by the host countries. In the case of the OECD countries, this difference has been estimated at around 40 percent of the total value (OECD, 2008), and this large difference is confirmed by Eurostat data (Hanemann and Rosen, 2012). Second, the geographic distribution of Chinese FDI is different from the distribution according to MOFCOM data. A new database published by the Heritage Foundation, ${ }^{5}$ which records transactions (of more than $\$ 100$ million) at firm level, shows that when financial centers such as Honk Kong are not counted as the final targets of investments, OECD countries, such as Australia, the USA, Canada and the UK attract the bulk of Chinese flows.

Finally, and in addition to the problems described above, official Chinese FDI data do not allow disaggregated and detailed investigation of the international strategies of multinational enterprises (MNEs) taking into account that they can engage in cross-border activities: a) by establishing a fully-owned subsidiary (greenfield FDI); b) by merging with a foreign firm (merger); c) by

\footnotetext{
${ }^{3}$ In 2006, when financial data started to be recorded, they represented 20 percent of total flows.

${ }^{4}$ Extreme bureaucracy and detailed screenings are two major reasons why private firms try to escape the approval process. Recent reforms to MOFCOM's approval system have simplified the approval process, raising the threshold for examination and approval to apply only to large investments (US $\$ 10 \mathrm{~m}$ to US $\$ 100 \mathrm{~m}$ ). For a detailed review of the investment policies in the context of Chinese OFDI, see Bernarsconi-Osterwalder et al. (2012).

${ }^{5}$ A description of the dataset is available at: http://www.heritage.org/research/projects/china-global-investment-trackerinteractive-map.
} 
acquiring a share of a foreign firm (acquisition and minority investment); or d) by entering a joint venture with a foreign firm.

\section{The literature on Chinese outward FDI}

In what follows we review the empirical literature on Chinese FDI focusing on the different data sources utilized, aimed at highlighting how they influence the empirical findings.

A large part of the empirical literature on Chinese FDI is aimed at investigating the relative importance of the traditional motivations for overseas investment flows. Most of these studies ${ }^{6}$ are based on MOFCOM approved investments, which, as explained above, suffer from several biases. A common finding in these studies is that Chinese FDIs are attracted mainly by the size of the host market, and the opportunity to access natural resources (Buckley et al., 2007; Kolstad and Wiig, 2012). A peculiar result is that Chinese investments are indifferent to economic (Buckley et al., 2007) and political instability, especially in resource rich countries (Kolstad and Wiig, 2012). Their location is also influenced by cultural proximity and geographic and psychic distance (Chou et al., 2011; Blomkvist and Drogendijk, 2013). The empirical studies mentioned do not find empirical support for the strategic asset-seeking objective highlighted in the Go Global strategy promoted by the Chinese Government (Deng, 2009). In qualitative case studies, focused on Chinese FDI in Europe, the intention to access strategic resources is instead a core motivation (Zhang and Filippov, 2009; Pietrobelli et al., 2011; Giuliani et al., 2014).

In light of the various concerns over the reliability of Chinese official statistics, a number of recent analyses at firm and deal level have attempted to refine the existing results on the determinants of Chinese outward FDI. Liao and Tsui (2012) use the Heritage Foundation database and show that factors related to (cultural and geographic) proximity lose their explanatory power because of the exclusion from the analysis of financial centers such as Hong Kong, while risk averseness and bad governance become not significant because of the increased weight of advanced countries as FDI recipients compared to lower income destinations.

In two papers using data on greenfield FDI provided by fDImarkets, Amighini et al. (2013a,b) show that the findings in the extant literature are likely to be strongly affected by both the sectoral allocation of the investment projects and the ownership structure of the investors. Amighini et al. (2013a) find that the asset-seeking motivation is statistically significant when the recipients are high-income countries and the investment is in the manufacturing industry. They also show that manufacturing FDIs are more likely in countries with a large market size, while investments in resource-intensive sectors are more often located in countries with low levels of GDP. Taking into account of the ownership structure of the investing companies, Amighini et al. (2013b) shed some

\footnotetext{
${ }^{6}$ Two exceptions are Buckley et al. (2007, 2008), which use SAFE data for the period 1991-2001 (See fn. 1).
} 
light on the indifference of Chinese investors to political risky countries finding that only State Owned Enterprises (SOEs), which are backed by government, are relatively indifferent to investing in politically weak contexts, especially those with large resource endowments (Ramasamy et al., 2012 and Duanmu, 2012 find similar results for smaller groups of Chinese firms). Instead, private Chinese MNEs are more likely to undertake internationalization following traditional approaches, including maximization of profits and exploitation of their competitive advantages (Lu et al., 2011 and Liang et al., 2012, based on two ad-hoc surveys of private companies, find similar results).

Firm-level analyses provide more information on Chinese MNEs' entry modes, often investigated only in case studies based analyses (see e.g. Zhang et al., 2011). An original survey of a sample of Chinese firms, selected among those with investments registered with MOFCOM, shows that wholly-owned subsidiaries are preferred if the investment is aimed at strategic asset seeking (Cui and Jiang, 2009).

The existing literature would seem to confirm that data limitations have reduced the scope of analyses of Chinese FDI. While some more recent work based on firm level information provides empirical information on the motivations and location choices of Chinese MNEs, further research is needed on issues related to firm organization.

\section{Analyzing Chinese Outward FDI Using Firm-level Data}

1. The EMENDATA database

The main data sources on bilateral FDI with a worldwide coverage are fDiMarkets, providing information on greenfield investments (i.e. new wholly-owned subsidiaries) from 2003; Zephyr (by Bureau van Dijk) and Thomson Reuters' SDC Platinum which provide data on M\&As and other minority investments (see the Appendix for a detailed description of these databases). These data sources are extensively used in the literature to investigate the international activities of both emerging and advanced multinationals, but so far they have been used separately (among others, see De Beule and van de Bulcke, 2012; Amighini and Franco, 2013; Amighini et al., 2013a,b).

As a matter of fact, the data from these sources are not directly comparable, as they differ in the way they are built: fDiMarkets is an event- or deal-based database, reporting each investment deal through which a wholly-owned subsidiary is established at a certain date by an investing firm while Bureau van Dijk’s Zephyr and Thomson Reuters’ SDC Platinum are firm-level databases reporting the ownership relationships between any parent firm and its affiliates and subsidiaries.

A new database called Emerging Multinationals' Events and Networks DATAbase (EMENDATA) is a major accomplishment in terms of harmonization and consolidation, making these three data sources comparable. EMENDATA includes all cross border greenfield investments, M\&As, and 
minority investments (corresponding to a share lower than 50 percent) from MNEs in emerging countries, ${ }^{7}$ between 2003 and $2011 .{ }^{8}$ It should be noted that 2003 as the first year in the database does not constitute a major limitation for the purpose of researching the outward expansion of Chinese firms, because the international expansion of Chinese companies only boomed in the early 2000s, promoted by the Go Global policy (Buckley et al., 2008).

EMENDATA provides information at the level of the individual deal, the investing company, and the global ultimate owner. The main deal level information include: a) entry mode; b) sector of specialization of the investing company and of the subsidiaries; c) activities undertaken by the subsidiaries; d) location of the subsidiaries; and e) number of jobs created.

It is also worth stressing that the number of deals is a more appropriate unit of analysis than the value of the investment when investigating the location strategies of multinationals and their investment motivations because the choice of a specific country and the motivation of the investment might be largely independent of the amount of capital invested. Moreover, the investment size varies widely across sectors, with resource-intensive sectors showing higher average investment size than consumer goods sectors or services. This is the main reason why several empirical studies have chosen the number of deals (and not the investment size) as their unit of analysis (among others see Ramasamy et al., 2012; Crescenzi et al., 2013, Amighini et al., 2013a; Amighini and Franco, 2013). ${ }^{9}$

An innovative feature of EMENDATA is that all the deals included are linked to firm-level (both investor and target companies) as well as group-level identifiers, which allows to group and analyze all the deals undertaken by the same global ultimate owner (GUO). Such coding procedure allows linking to the three original data sources - fDiMarkets, Zephyr and SDC Platinum - further firmlevel information, such as the ownership structure, the location of domestic and foreign subsidiaries, the sector of economic activity, the consolidated and unconsolidated balance indicators, some firm size variables, the names and types of shareholders and the patenting activity. All these additional variables have been sourced by the database Orbis, published by Bureau van Dijk. Other sources of information on GUOs that can be linked to the information in EMENDATA include the FT Emerging 500, the Fortune Global 500, and the EU Industrial R\&D Investment Scoreboard.

\footnotetext{
${ }^{7}$ There is no official definition of an emerging country. EMENDATA includes all countries in the lower and upper middle-income groups according to the World Bank classification.

${ }^{8}$ EMENDATA includes all investments registered as completed deals. Rumors are monitored and reported as such until they eventually end up in a deal, or otherwise discarded from the database.

${ }^{9}$ There is an additional reason for this choice, which is methodological. Even if the databases provide information on the value of the investment, in most of the cases this is based on the announced level rather than the actual (i.e. the realized) one. In addition, at least for greenfield investments, the value reported is often obtained through an estimation (see Amighini et al., 2013b, for a discussion on this matter).
} 
With EMENDATA, it is also possible to analyze the interplay between different dimensions, namely at the level of deal, investing firm, group, sector, home and host country. ${ }^{10}$ Specifically, at the deal level, it allows investigating the distribution of investments across sectors, business activities and countries distinguishing by deal type, company and group. Moreover, it allows mapping the foreign expansion strategies of firms and groups in a more comprehensive way compared to what could be done so far with non-comparable data on different types of foreign activities and at country and regional levels it permits to examine the location choices disaggregated by sector and deal type. The following sub-section shows a detailed and comprehensive analysis of the multinational activity of Chinese companies across various dimensions, while section IV explores more in depth the potential for analyses at the group level.

\section{An overview of Chinese FDI based on EMENDATA}

EMENDATA includes 3,020 deals involving Chinese investing companies, ${ }^{11}$ of which 2,092 are greenfield investments, $623 \mathrm{M} \& A s$, and 305 minority investments. ${ }^{12}$ Information at the deal level allows identifying the location of both the direct acquirer and the ultimate owner and whether a transit through a fiscal haven is involved therefore assessing the relative importance of fiscal paradises as location choices. We have also checked whether all the deals originating from fiscal heavens can be ultimately attributed to a Chinese group and therefore can be considered as Chinese investments. Based on this, we have added some additional deals to those originally included in EMENDATA.

Figure 1 presents the number of deals distinguishing between the different modes of entry. All the different types of deals have increased in the time span included in EMENDATA, with the number of greenfield investments showing the most dramatic increased since 2006 and M\&As and minority investments displaying a slower growth rate. These trends can be explained by the recent effort to extend the provisions of the Go Global policy to private firms (Luo et al., 2010) whose internationalization strategy is largely undertaken by means of wholly owned subsidiaries rather than M\&As.

\section{FIGURE 1 HERE}

\footnotetext{
${ }^{10}$ For a recent example of work using EMENDATA, see Piscitello et al. (2014).

${ }^{11}$ A very careful manual cleaning of the deals was undertaken in collaboration with Chinese partners in order to exclude deals undertaken by investors other than companies, such as sovereign funds, individual investors, and investors who could not be identified.

${ }^{12}$ The source of information on M\&A and minority investments is SDC Platinum, which includes 928 deals from China (in Zephir there are 816 deals). For the sub-sample of Chinese FDIs in the EU27 (see Table 5), both SDC Platinum and Zephyr are taken into account and the two sources are complementary. We plan to extend the integration of these two sources for all the deals.
} 
Table 1 presents the geographic distribution of Chinese investments. The main destination is Asia with 1,166 deals, corresponding to almost 40 percent of all deals, followed closely by Europe. This is different from the distribution suggested by official data, which shows Asia accounting for 71 percent of the total stock of Chinese FDI, and North America and Europe together receiving slightly over 10 percent. It is interesting that according to MOFCOM statistics Latin America accounts for over 15 percent of total stock of Chinese FDI (MOFCOM, 2012), a much higher figure than suggested by EMENDATA. This can be explained by the reduced role played by fiscal heavens located in the region (i.e. the Cayman Islands and the Virgin islands) in EMENDATA. When distinguishing by types of deals, Asia is the main destination for M\&As, followed by North America, and Europe is the first destination for greenfield investments, closely followed by Asia.

\section{TABLE 1 HERE}

Table 2 lists the top ten recipient countries based on EMENDATA and compares them with the top recipients in the official statistics (MOFCOM, 2012), recalling that the units of analysis are different: total number of deals in EMENDATA and value of the FDI stock in MOFCOM. As already emphasized, the geographical distribution of Chinese FDI based on MOFCOM data is strongly biased in favor of financial centers and fiscal heavens, the top three destinations being Hong Kong (61.6 percent of the total), Virgin Islands (6.9 percent) and Cayman Islands (5.1 percent). Hong Kong is also the main recipient in EMENDATA, but measured as number of deals it represents only 11 percent of the total, a much lower share compared with the 61.6 percent according to MOFCOM. Among the other countries listed, there are some common destinations such as Australia, USA, Singapore, Canada, and Russia. EMENDATA also identifies other key recipient countries such as Germany, UK, India and Japan. It is interesting that Germany does not appear in MOFCOM as a major recipient of Chinese investments, but is ranked first for greenfield investments in EMENDATA. In fact, Germany receives the largest number of Chinese greenfield investments in Europe, made by private owned companies, investments which are often not recorded by MOFCOM, and in many cases of small scale, measured by their value (Giuliani et al., 2014; Hanemann and Rosen, 2012).

TABLE 2 HERE 
These differences are not surprising. EMENDATA with firm level information allows the precise identification of the final destination of the investment, considerably reducing the relevance of round-tripping (for transit locations such as Hong Kong and the other fiscal heavens), which are the main destinations according to MOFCOM's approval system. In addition, our results are highly consistent with other recent attempts to assess the actual geographic distribution of Chinese investments, which show that countries such as the US, Germany, Australia and Canada account for a larger share than that indicated by MOFCOM. ${ }^{13}$

Based on sector disaggregation ${ }^{14}$, services represent 30 percent of the total number of investments followed by investments in mining (5 percent) (Table 3). If we consider the modes of entry, manufacturing is the main specialization for greenfield investment (71 percent), and services attracts 55 percent of M\&A deals, followed by manufacturing with 35 percent.

\section{TABLE 3 HERE}

Table 4 combines a geographical and sector breakdown for each type of deal. Europe, and especially EU27, is the top destination for greenfield FDI in manufacturing with 42.2 percent of the total number of greenfield investments, followed by Asia with 30.4 percent, which is the favorite destination for greenfield FDI in services with 48 percent. In relation to M\&A, in services, 57.6 percent of M\&As are in Asia with a very high share in Hong Kong, followed by the USA.

\section{TABLE 4 HERE}

From this descriptive analysis, it is clear that an empirical investigation about FDI based on a comprehensive database such as EMENDATA provides a comprehensive picture of China's internationalization strategy since the early 2000s, and offers some new insights compared to the official statistics.

\section{From Firm-level to Group-level Analysis}

Although it is widely acknowledged that a large part of world economic activity and trade is accounted for by business groups (BGs), i.e. groups of legally separated firms linked through

\footnotetext{
${ }^{13}$ For a comparison, see, for instance, the China Global Investment Tracker by the Heritage Foundation, or the China Investment Monitor by the Rhodium Group.

${ }^{14}$ In the rest of this section we focus only on greenfield and M\&A, which represent the two main modes of entry of Chinese companies in foreign markets.
} 
ownership relationships (see e.g. BEA, 2012; Altomonte et al., 2012), most studies look at the international expansion of emerging market firms taking the individual investing firms as the unit of analysis. Multinationals can be considered a particular type of BG and their internationalization strategies should be analyzed taking into account that individual firms are embedded in networks of ownership relationships with other firms within complex organizational forms.

So far the lack of a comprehensive database at the deal level has limited in depth research about the multinational strategies of Chinese companies. In EMENDATA, Chinese firms that are involved in more than one deal undertake 46 percent of total Chinese investments. ${ }^{15}$ Therefore, group-level analysis based on EMENDATA allows for "comparative institutional analysis at the level of the economic transaction, incorporating variation both in the content of that transaction and in the structure of the institutional environment” (Henisz, 2000, p. 361). Assuming as a working hypothesis that different degrees of decision-making power apply to different layers of ownership, each single investment cannot be analyzed separately from deals undertaken by other firms in the same BG.

Table 5 lists the top ten BGs ranked according to the number of deals undertaken between 2003 and 2011 exemplifying FDI activity among the main Chinese BGs based on EMENDATA information. We observe that the most common mode of entry, regardless of the sector of specialization is by the establishment of new activities (greenfield). Only one group, ChemChina, has also been involved in a significant number of acquisitions.

\section{TABLE 5 HERE}

In relation to the top five groups ${ }^{16}$ for number of deals, Table 6 shows the main destinations of their investments in the EU27. The UK attracts the highest number of investments from the top five Chinese BGs and also most of their acquisitions. Although the internationalization strategies of all the BGs are quite diverse with regard to their geographical distribution, Huawei, Suntech and ZTE have a broader geographical scope than SAIC which main investment destination is the UK, plus one investment each in Italy and Germany, both countries with a strong tradition in the automotive sector. The main destination for ChemChina is France where there are 11 investments, including 3 acquisitions; besides, important target countries are also the UK and Spain.

\footnotetext{
${ }^{15}$ This is an underestimation of multiple-deal companies because it includes only those undertaking more than 1 investment in a EU27 country. Although beyond the scope of this paper, EMENDATA also includes information on domestic deals and according to our database, Chinese groups appear quite active in the domestic market accounting for 87.5 percent of total M\&A and 91 percent of the minority investments.

${ }^{16}$ From the top 5 groups, we exclude $I C B C$, a commercial bank that is involved only in financial services, and include Suntech Power, a manufacturing company specialized in alternative energies.
} 


\section{TABLE 6 HERE}

Since BG activities are often characterized by diversification, we have examined the spread of foreign affiliates in Europe according to their sector and business activity (Table 7). There is generally no significant diversification effect related to sector distribution with the exception of SAIC (which has investments in both the automotive and the financial services sectors). Moreover, well established telecommunication companies such as Huawei and ZTE have approached Europe with a variety of motivations, especially related to the development of skills in high value added activities such as R\&D, design, and training, and the intention to serve local markets through dedicated sales and technical support centers. Penetration in local markets seems to be a major motivation for Suntech in the decision to entry into Europe.

\section{TABLE 7 HERE}

In addition to describing the deals undertaken by Chinese groups according to their geographical target and spread of activities, the group level coding in EMENDATA allows other research directions. The matching data at deal, subsidiary and group level provides insights into the multiple internationalization strategies of Chinese groups. This involves exploiting deal characteristics and analyzing them jointly with the information on parent companies and subsidiaries (e.g. indicators from unconsolidated balances), as well as data on BGs (e.g. indicators from consolidated balances). The literature includes some recent works adopting a BG perspective to analyze issues such as the relationships between the organizational structure and intra-firm production decisions (e.g. Altomonte and Rungi, 2013, for a large sample of BGs including a few Chinese groups).

There are three main areas for future research linking work on emerging market multinationals with BG analysis. The first deals with measuring the degree of complexity of BGs as hierarchical structures and integrating this information with the spread of different business activities by foreign affiliates (see Table 7) and the motivations for each investment within the same BG. The second and related avenue of research introduces global value chain analysis (see Crescenzi et al., 2013) in order to understand how much and which of the key activities along the chain are internalized within the group. The third is related to investigating how intra-group strategies affect group performance and productivity, to provide empirical evidence on reverse spillovers from investments. 


\section{Conclusion}

Following the rapid international expansion of Chinese firms there has been a surge in the empirical literature exploring their investment patterns and strategies. Investigating the rationale and motivations behind those investments, the characteristics of investing firms, and their impact on both host and home economies is a crucial step towards achieving a sound and comprehensive understanding of national (i.e. investment attraction policies) and multilateral (i.e. international investment agreements) political decisions.

Data reliability is crucial for analyzing Chinese firms' internationalization strategies. So far, information on Chinese FDI has mainly relied on aggregate data from official statistics that despite recent commitments to catch up with international standards still suffer from several shortcomings. Moreover, these data are collected to achieve different objectives from those that inspire international business studies and ignore several factors including industry breakdowns, ownership structures and modes of entry.

The contribution of this paper to the existing debate is twofold. First, it provides a systematic analysis of the main methodological drawbacks of MOFCOM data, the implications in terms of misinterpretation of the trends they depict, and the partial explanation they provide for the rising role of Chinese FDI. Second, it introduces a novel firm-level database (EMENDATA) compiled by matching different data on various types of cross-border deals, including information on group structures, which allows new empirical analyses and provides new insights on the rapidly increasing presence of Chinese companies abroad. We show that these data provide a more informative and comprehensive assessment of the geographical and specialization patterns of Chinese OFDI. In particular, we show that Chinese companies are geographically more widespread than official statistics would suggest, and that the overemphasis on investments in natural resources is mostly due to their higher relative size compared to other sectors, such as manufacturing, which attracts by far the largest number of Chinese investments.

EMENDATA opens up new avenues for empirical research by allowing multilevel analysis of multinational investment patterns and strategies including (parent and subsidiary) firm, industry, and (home and host) country perspectives. In particular, it allows the mapping of investments belonging to the same BG, and the possibility to integrate different research fields such as multinational strategies, BG formation, value chain analysis, the links between ownership structure and organization of international production, and how all those affect group performance and productivity. We plan to exploit the rich information available in EMENDATA in future research. 


\section{References}

Altomonte Carlo and Armando Rungi 2013, "Business groups as hierarchies of firms. Determinants of vertical integration and performance,” European Central Bank Working Paper Series, n. 1554.

Altomonte, Carlo, Filippo di Mauro, Gianmarco. I. P. Ottaviano, Armando Rungi and Vincent Vicard, 2012, "Global Value Chains during the Great Trade Collapse: a Bullwhip Effect?" ECB Working Paper N. 1412.

Amighini Alessia, Roberta Rabellotti and Marco Sanfilippo, 2013a, “China's outward FDI: An industry-level analysis of host-country determinants," Frontiers of Economics in China, Vol. 8, No. 3, pp. 903-936.

Amighini Alessia, Roberta Rabellotti and Marco Sanfilippo, 2013b, “Do Chinese State-Owned and private Enterprises Differ in their Internationalization Strategies?” China Economic Review, Vol. 27, pp. 312-235.

Amighini Alessia and Chiara Franco, 2013, “A sector perspective on Chinese outward FDI: The automotive case,” China Economic Review, Vol. , pp. 148-161.

BEA, 2012, U.S. Multinational Companies. Operations of U.S. Parents and Their Foreign Affiliates in 2010. Washington, DC: US Bureau of Economic Analysis.

Bhabra, Harjeet S. and Jiayin Huang, 2013, “An empirical investigation of mergers and acquisitions by Chinese listed companies, 1997-2007,” Journal of Multinational Financial Management, Vol. 23, No. 3, pp. 186-207.

Bernarsconi-Osterwalder, Nathalia, Lisa Johnson and Jianping Zhang, 2012, Chinese Outward Investment: An emerging policy framework, Winnipeg: the International Institute for Sustainable Development.

Beugelsdijk, Sjoerd, Jean-Francois Hennart, Arjen Slangen, and Roger Smeets, 2010, "Why and how FDI stocks are a biased measure of MNE affiliate activity,” Journal of International Business Studies, Vol. 41, No. 9, pp. 1444-1459.

Blomkvist, Katarina and Rian Drogendijk, 2013, "The Impact of Psychic Distance on Chinese Outward Foreign Direct Investments,” Management International Review, Vol. 53, No. 5, pp. 659-686.

Buckley, Peter J., Jeremy L. Clegg, Adam R. Cross, Xin Liu, Hinrich Voss and Ping Zheng, 2007, “The determinants of Chinese outward foreign direct investment”, Journal of International Business Studies, Vol. 38, No. 4, pp. 499-518.

Buckley, Peter J., Adam R. Cross, Hui Tan, Liu Xin and Hinrich Voss, 2008, "Historic and emergent trends in Chinese outward direct investment,” Management International Review, 
Vol. 48, No. 6, pp.715-748.

Chou, Kuang-Hann, Chien-Hsun Chen and Chao-Cheng Mai, 2011, "The impact of third-country effects and economic integration on China's outward FDI,” Economic Modelling, Vol. 28, No. 5, pp. 2154-2163.

Cui, Lin and Fuming Jiang, 2009, “FDI entry mode choice of Chinese firms,” Journal of World Business, Vol. 44, No. 4, pp. 434-444.

Crescenzi, Riccardo, Carlo Pietrobelli and Roberta Rabellotti, 2013, "Innovation Drivers, Value Chains and the Geography of Multinational Corporations in Europe,” Journal of Economic Geography, doi: 10.1093/jeg/lbt018

Davies, Ken, 2013, “China Investment Policy: an Update,” Paris: OECD Working Papers on International Investment, No. 2013/1.

De Beule, Filip and Daniel Van Den Bulcke, 2012, "Locational determinants of outward foreign direct investment: an analysis of Chinese and Indian greenfield investments,” Transnational Corporations, Vol. 21, No. 1, pp. 1-34.

Deng, Ping, 2009, "Why do Chinese firms tend to acquire strategic assets in international expansion?” Journal of World Business, Vol. 44, No. 4, pp. 74-84.

Duanmu, Jing-Lin, 2012, "Firm heterogeneity and location choice of Chinese Multinational Enterprises,” Journal of World Business, Vol. 47, No. 1, pp. 64-72

Fan, Di, Cherrie J. Zhu and Chris Nyland, 2012, "Factors affecting global integration of Chinese multinationals in Australia: A qualitative analysis,” International Business Review, Vol. 21, No. 1, pp. 13-26.

Giuliani Elisa, Sara Gorgoni, Christina Guenther and Roberta Rabellotti, 2014, "Emerging-market MNEs investing in Europe. A typology of subsidiary global-local connections,” International Business Review, Vol. 23, No. 4, pp. 680-691.

Hanemann, Thilo and Daniel H. Rosen, 2012, China Invests in Europe Patterns, Impacts and Policy Implications, New York: Rhodium Group.

Henisz, Witold J., 2000, “Institutional Environments for Multi-National Investment,” Journal of Law, Economics and Organizations, Vol. 16, No. 2, pp. 334-364.

Kolstad, Ivar and Arne Wiig, 2012, “What Determines Chinese Outward FDI?” Journal of World Business, Vol. 47, No. 1, pp. 26-34.

Liang, Xiaoya, Xiongwen Lu and Lihua Wang, 2012, “Outward internationalization of private enterprises in China: The effect of competitive advantages and disadvantages compared to home market rivals,” Journal of World Business, Vol. 47, No. 1, pp. 134-144.

Liao, Wei and Kevin K. Tsui, 2012, “China’s Outward Direct Investment: Evidence from a new micro database”, Hong Kong: HKIMR Working Paper No.17/2012. 
Lu, Jiangyong, Xiaohui Liu and Hongling Wang, 2011, "Motives for Outward FDI of Chinese Private Firms: Firm Resources, Industry Dynamics, and Government Policies,” Management and Organizational Review, Vol. 7, No. 2, pp. 223-248.

Luo, Yadong, Qiuzhi Xue and Binjie Han, 2010, “How emerging market governments promote outward FDI: Experience from China,” Journal of World Business, Vol. 45, No. 1, pp. 6879.

MOFCOM, 2012, China Commerce Yearbook, Beijing: Ministry of Commerce.

OECD, 2008, OECD Investment Policy Reviews-China 2008: Encouraging Responsible Business Conduct, Paris: OECD.

Pietrobelli, Carlo, Roberta Rabellotti and Marco Sanfilippo, 2011, “Chinese FDI Strategy in Italy: The “Marco Polo” Effect," International Journal of Technological Learning, Innovation and Development, Vol. 4, No. 4, pp. 277-291.

Piscitello, Lucia, Roberta Rabellotti and Vittoria G. Scalera, 2014,“Chinese and Indian acquisitions in Europe: The relationship between motivation and entry mode choice,” in Annette Risberg, Davide King and Olimpia Meglio, eds,, The Routledge Companion to Merger and Acquisition. London: Routledge.

Ramasamy, Bala, Matthew Yeung and Sylvie Laforet, 2012, “China’s outward foreign direct investment: Location choice and firm ownership,” Journal of World Business, Vol. 47, No. 1, pp. 17-25.

Rosen, Daniel H. and Thilo Hanemann, 2009, “China’s Changing Outbound Foreign Direct Investment Profile: Drivers and Policy Implications”, Peterson Institute for International Economics Policy Brief N. 09-14.

Sutherland, Dylan and Lutao Ning, 2011, “Exploring ‘onward-journey’ ODI strategies in China’s private sector businesses,” Journal of Chinese Economic and Business Studies, Vol. 9, No. 1, pp. 43-65.

Zhang, Ying and Sergei Filippov, 2009, “Internationalization of Chinese firms in Europe,” UNUMerit Working Paper Series N. 2009-041.

Zhang, Jieyin, Alberto Di Minin and Xiaohong Quan, 2011, “A Comparison of International R\&D Strategies of Chinese Companies in Europe and the U.S.”, Technology Management Conference (ITMC), 2011. 
Figure 1. Number of Chinese FDI by deal type (2003-2011)

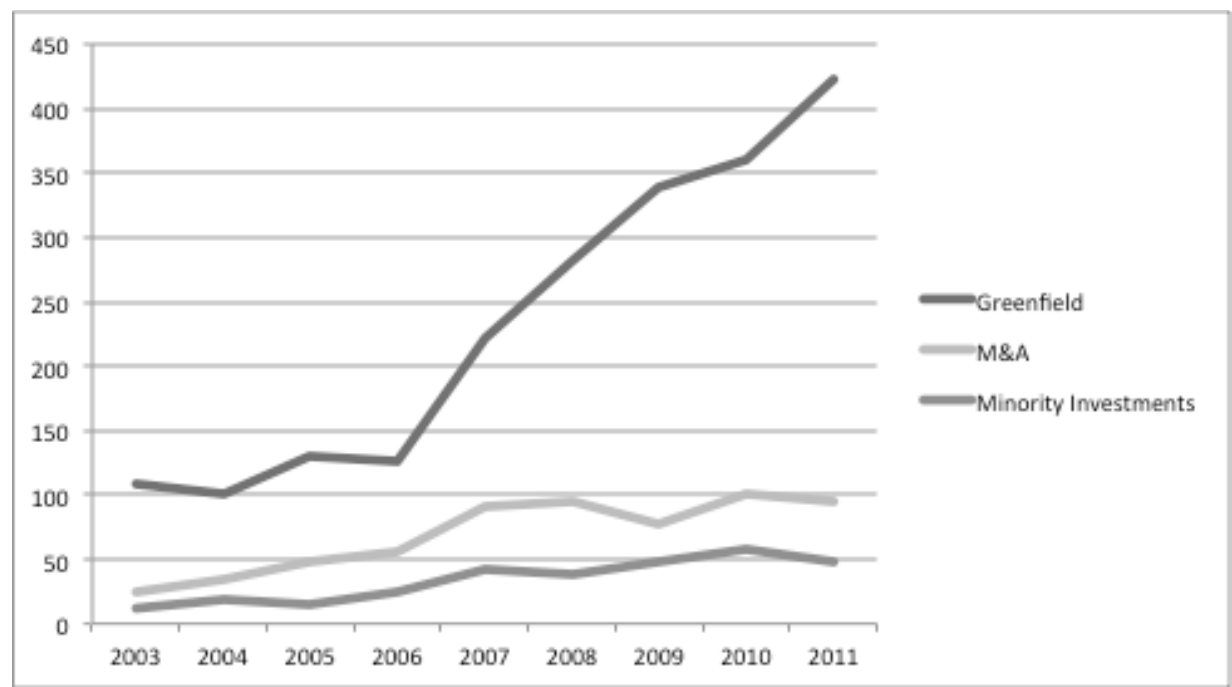

Source: EMENDATA

Table 1. Chinese FDI by target regions (N. of deals: 2003-2011)

\begin{tabular}{|l|c|c|c|c|c|}
\hline Area & Greenfield & M\&A & $\begin{array}{c}\text { Minority } \\
\text { investments }\end{array}$ & Total & $\begin{array}{c}\text { \% of } \\
\text { total }\end{array}$ \\
\hline Asia & $\mathbf{7 4 2}$ & $\mathbf{3 0 0}$ & $\mathbf{1 2 4}$ & $\mathbf{1 . 1 6 6}$ & $\mathbf{3 8 . 6}$ \\
\hline Hong Kong & 108 & 174 & 65 & 347 & 11.5 \\
\hline Europe & $\mathbf{7 9 7}$ & $\mathbf{9 7}$ & $\mathbf{2 7}$ & $\mathbf{9 2 1}$ & $\mathbf{3 0 . 5}$ \\
\hline EU27 & 670 & 84 & 23 & 777 & 25.7 \\
\hline Germany & 268 & 19 & 4 & 291 & 9.6 \\
\hline Northern and Central America & $\mathbf{2 4 7}$ & $\mathbf{1 6 5}$ & $\mathbf{5 6}$ & $\mathbf{4 6 8}$ & $\mathbf{1 5 . 5}$ \\
\hline US & 186 & 92 & 24 & 302 & 10.0 \\
\hline Africa & $\mathbf{1 3 5}$ & $\mathbf{1 0}$ & $\mathbf{8}$ & $\mathbf{1 5 3}$ & $\mathbf{5 . 1}$ \\
\hline Latin America & $\mathbf{1 1 2}$ & $\mathbf{1 0}$ & $\mathbf{1 3}$ & $\mathbf{1 3 5}$ & $\mathbf{4 . 8}$ \\
\hline Oceania & $\mathbf{5 9}$ & $\mathbf{4 1}$ & $\mathbf{7 7}$ & $\mathbf{1 7 7}$ & $\mathbf{5 . 9}$ \\
\hline Total & $\mathbf{2 0 9 2}$ & $\mathbf{6 2 3}$ & $\mathbf{3 0 5}$ & $\mathbf{3 0 2 0}$ & $\mathbf{1 0 0 . 0}$ \\
\hline
\end{tabular}

Source: EMENDATA 
Table 2. The Top 10 Target Economies for Chinese FDI

\begin{tabular}{|c|c|c|c|c|c|c|c|}
\hline \multicolumn{9}{|c|}{ EMENDATA } & \multicolumn{2}{c|}{ MOFCOM } \\
\hline Country & $\begin{array}{c}\text { percent \# } \\
\text { deals* }\end{array}$ & Country & $\begin{array}{l}\text { percent \# } \\
\text { Greenfield } \\
\text { M\&A }\end{array}$ & Country & Country & $\begin{array}{c}\text { ercent of } \\
\text { total } \\
\text { stock** }\end{array}$ \\
\hline $\begin{array}{c}\text { Hong } \\
\text { Kong }\end{array}$ & 11 & Germany & 13 & Hong Kong & 28 & Hong Kong & 61.6 \\
\hline USA & 10 & USA & 9 & USA & 15 & Virgin Isld. & 6.9 \\
\hline Germany & 10 & Hong Kong & 5 & Australia & 6 & Cayman Isld. & 5.1 \\
\hline Australia & 5 & UK & 5 & Canada & 5 & Australia & 2.6 \\
\hline UK & 4 & Russia & 4 & Singapore & 5 & Singapore & 2.5 \\
\hline Singapore & 3 & India & 4 & Virgin Island & 5 & USA & 2.1 \\
\hline India & 3 & Brazil & 3 & Japan & 4 & Luxembourg & 1.7 \\
\hline Canada & 3 & Vietnam & 3 & Germany & 3 & South Africa & 1.0 \\
\hline Russia & 3 & Singapore & 2 & UK & 3 & Russia & 0.9 \\
\hline Japan & 3 & Taiwan & 2 & Netherlands & 2 & Canada & 0.9 \\
\hline Total \# & 3020 & & 2092 & & 623 & Million \$ & 74654 \\
\hline
\end{tabular}

Source: EMENDATA and MOFCOM (2012).

Notes: * Total number of Greenfield, M\&A and Minority Investments

** Refer to the share over the total stock at 2011

Table 3. Chinese FDI by sector (\# and Percent)

\begin{tabular}{|c|c|c|c|c|}
\hline Sector & Greenfield & percent & M\&A & percent \\
\hline Agriculture & 0 & 0 & 6 & 1 \\
\hline Construction & 43 & 2 & 4 & 1 \\
\hline Extraction & 90 & 4 & 54 & 9 \\
\hline Manufacturing & 1.488 & 71 & 219 & 35 \\
\hline Services & 471 & 23 & 340 & 55 \\
\hline Total & 2.092 & 100 & 623 & 100 \\
\hline
\end{tabular}


Table 4. Chinese FDI by Destination, Sector and Deal Type (\# and Percent)

\begin{tabular}{|c|c|c|c|c|c|c|c|c|c|c|c|c|}
\hline \multirow{3}{*}{ Area } & \multicolumn{6}{|c|}{ Greenfield } & \multicolumn{6}{|c|}{ M\%A } \\
\hline & \multicolumn{2}{|c|}{ Extraction } & \multicolumn{2}{|c|}{ Manufacturing } & \multicolumn{2}{|c|}{ Services } & \multicolumn{2}{|c|}{ Extraction } & \multicolumn{2}{|c|}{ Manufacturing } & \multicolumn{2}{|c|}{ Services } \\
\hline & $\#$ & percent & $\#$ & percent & \# & percent & $\#$ & percent & $\#$ & percent & \# & percent \\
\hline Asia & 50 & 55.6 & 453 & 30.4 & 226 & 48.0 & 15 & 27.8 & 81 & 37.0 & 196 & 57.6 \\
\hline $\begin{array}{l}\text { Hong } \\
\text { Kong }\end{array}$ & 2 & 2.2 & 38 & 2.6 & 68 & 14.4 & 5 & 9.3 & 38 & 17.4 & 129 & 37.9 \\
\hline Europe & 8 & 8.9 & 628 & 42.2 & 142 & 30.1 & 8 & 14.8 & 63 & 28.8 & 26 & 7.6 \\
\hline EU27 & 5 & 5.6 & 535 & 36.0 & 118 & 25.1 & 6 & 11.1 & 59 & 26.9 & 19 & 5.6 \\
\hline Germany & 2 & 2.2 & 227 & 15.3 & 36 & 7.6 & 1 & 1.9 & 15 & 6.8 & 3 & 0.9 \\
\hline $\begin{array}{l}\text { Northern } \\
\text { Central } \\
\text { America }\end{array}$ & 6 & 6.7 & 185 & 12.4 & 56 & 11.9 & 11 & 20.4 & 61 & 27.9 & 91 & 26.8 \\
\hline USA & 2 & 2.2 & 143 & 9.6 & 41 & 8.7 & 5 & 9.3 & 35 & 16.0 & 52 & 15.3 \\
\hline Africa & 19 & 21.0 & 93 & 6.3 & 12 & 2.5 & 3 & 5.6 & 1 & 0.4 & 6 & 1.8 \\
\hline $\begin{array}{l}\text { Latin } \\
\text { America }\end{array}$ & 5 & 5.6 & 91 & 6.1 & 16 & 3.4 & 5 & 9.3 & 5 & 2.3 & $\mathbf{0}$ & 0.0 \\
\hline Oceania & 2 & 2.2 & 38 & 2.6 & 19 & 4.1 & 12 & 22.1 & 8 & 3.6 & 21 & 6.2 \\
\hline Total & 90 & 100.0 & 1,488 & 100.0 & 471 & 100.0 & 54 & 100.0 & 219 & 100.0 & 340 & 100.0 \\
\hline
\end{tabular}

Source: EMENDATA 
Table 5. Top Ten Chinese Groups Investing in the EU27, by Deal Type (2003-2011)

\begin{tabular}{|l|c|c|c|}
\hline & $\begin{array}{c}\text { Total \# } \\
\text { of deals }\end{array}$ & Greenfield & M\&A \\
\hline Huawei Technologies & $\mathbf{5 2}$ & 52 & 0 \\
\hline ZTE & $\mathbf{2 4}$ & 24 & 0 \\
\hline China National Chemical (ChemChina) & $\mathbf{2 2}$ & 13 & 9 \\
\hline $\begin{array}{l}\text { Industrial and Commercial Bank of } \\
\text { China(ICBC) }\end{array}$ & $\mathbf{1 5}$ & 15 & 0 \\
\hline $\begin{array}{l}\text { Shanghai Automotive Industry Corporation } \\
\text { (SAIC) }\end{array}$ & $\mathbf{1 1}$ & 8 & 3 \\
\hline Suntech Power Holdings & $\mathbf{1 0}$ & 9 & 1 \\
\hline Bank of China & $\mathbf{8}$ & 8 & 0 \\
\hline YingKe & $\mathbf{8}$ & 8 & 0 \\
\hline Chint Group & $\mathbf{7}$ & 7 & 0 \\
\hline LENOVO & $\mathbf{6}$ & 6 & 0 \\
\hline
\end{tabular}

Source: EMENDATA

Table 6. Total Number of Deals by the Top 5 Chinese Groups in the EU27 Countries*

\begin{tabular}{|c|c|c|c|c|c|}
\hline & Huawei & ChemChina & ZTE & SAIC & SUNTECH \\
\hline $\begin{array}{l}\text { United } \\
\text { Kingdom }\end{array}$ & 5 & $4(3)$ & 2 & $9(3)$ & 1 \\
\hline France & 5 & $11(3)$ & 4 & & 1 \\
\hline Germany & 6 & & 6 & 1 & 2 \\
\hline Spain & 4 & $4(1)$ & 1 & & 1 \\
\hline Italy & 7 & 1 & & 1 & 3 \\
\hline Hungary & 7 & & & & \\
\hline Romania & 4 & & 3 & & \\
\hline Netherlands & 3 & & 1 & & \\
\hline Belgium & 2 & (2) & & & \\
\hline Sweden & 3 & & 2 & & \\
\hline $\begin{array}{l}\text { Other } \\
\text { countries }\end{array}$ & 6 & & 5 & & 1 \\
\hline
\end{tabular}

* Number of acquisitions in parenthesis

Source: EMENDATA 
Table 7. Number of Greenfield Investments by the Top 5 Chinese Groups in the EU27 countries by business activity (\#)

\begin{tabular}{|l|c|c|c|c|c|c|}
\hline \multicolumn{1}{|c|}{ Industry activity } & Huawei & ChemChina & ZTE & SAIC & Suntech & ZTE \\
\hline Customer Contact Center & 3 & & & & & \\
\hline Design, Development and Testing & 14 & 1 & 5 & 3 & & 5 \\
\hline Education and Training & 2 & & 1 & & & 1 \\
\hline Headquarters & 5 & & 5 & & 1 & 5 \\
\hline ICT and Internet Infrastructure & & & 1 & & & 1 \\
\hline Logistics, Distribution and Transportation & 2 & & & & & \\
\hline Manufacturing & 2 & 12 & 2 & 2 & & 2 \\
\hline Research and Development & 6 & & 2 & & & 2 \\
\hline Retail & & & & 3 & & \\
\hline Sales, Marketing and Support & 14 & & 7 & & 8 & 7 \\
\hline Shared Services Center & 1 & & & & & \\
\hline Technical Support Center & 3 & & 1 & & & 1 \\
\hline
\end{tabular}

Source: EMENDATA 


\section{Appendix}

fDiMarkets is a crossborder investment monitor database maintained by Financial Times Business, a specialist division of the Financial Times group. fDiMarkets is the only online database tracking crossborder greenfield investments (including joint ventures if they lead to a new physical operation) covering all sectors and countries worldwide, with data collected since 2003. It provides real-time monitoring of investment projects, reporting: the name of investing company and of the parent company, the investment locations, the sectoral specialization, the type of business activity carried out by the foreign subsidiary, the value of the investment (in many cases an estimation of it) and the number of jobs created.

Zephyr is a commercial database by Bureau van Dijk (BvD) containing M\&As, joint venture, IPO, private equity, venture capital deals and investment rumors. It is updated hourly. The information provided includes: the type of deal (e.g. merger, acquisition); the status of the deal (completed or not); the value of the target and the financial information about the firms involved in the deal, including their country of origin and the other firm activities. Company information is available for the target, the acquirer and the vendor, predominantly sourced from BvD Orbis.

SDC Platinum is a commercial database by Thomson Reuters containing information on M\&As, syndicated loans, private equity, and project finance. It also provides a database for analyzing investment banking and deal trends, identifying comparable deals, monitoring deal activity, and generating industry-leading league tables and market-share analysis.

The types of deals contained in the three databases are defined as follows:

- Greenfield Investments: a foreign direct investment where a parent company starts a new venture in a foreign country by constructing new facilities from the ground up;

- Mergers: where there is a one-for-one swap of shares in the new company and the deal involves a 'merging of equals'. If the swap is not on equal terms, the deal is coded as an Acquisition. In Mergers the original companies are entered into the deal record as Acquirer and Target;

- Acquisitions: any deal where the Acquirer ends up with 50 percent or more of the equity of the Target;

- Minority stakes: when the Acquirer purchases a number of shares in the Target and the resulting stake is less than 50 percent. 